\title{
Gender-Inclusive Approaches in the Energy Sector
}

\section{Introduction}

\section{Gender and Energy: What Is the Link?}

Low accessibility of energy resources by low-income households and disadvantaged groups (including women) exacerbates the global issues of poverty, women's marginalization, urbanization, and population. For instance, studies have shown that as the use of traditional biomass fuel increases due to persistent lack of access to clean energy, female fertility increases, life expectancy decreases, infant and child mortality increases, and annual population growth rate increases. ${ }^{1}$ On the other hand, in communities where people are aware of sustainable, safe, and equitable use of energy, the patterns for energy generation, distribution, and consumption tend to be more responsible, inclusive, and efficient. This correlation between energy and social issues unravels the implications of the issue of energy poverty and underscores the need to attend to both the supply and demand sides of energy generation and distribution.

Reddy defines energy poverty as "the absence of sufficient choice in accessing adequate, affordable, reliable, high-quality, safe, and environmentally benign energy services to support economic and human development." $A$ measure of energy poverty is one's "inability to cook with modern cooking fuels and the lack of a bare minimum of electric lighting for reading or for other household and productive activities at sunset."

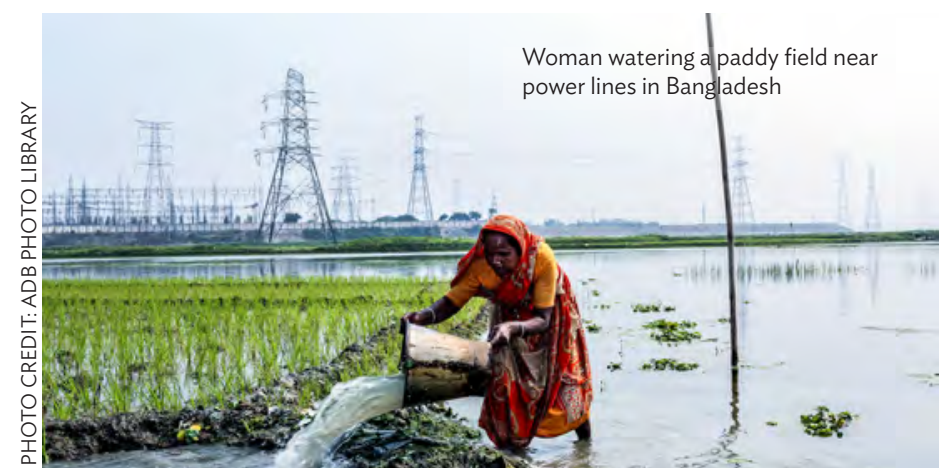

\section{ADB Initiatives in Gender Mainstreaming in the Energy Sector}

Efforts to mainstream gender equality in the energy sector are in line with Strategy 2020 of the Asian Development Bank (ADB), which includes gender equity among five drivers of change toward inclusive growth, ${ }^{4}$ and with the 1998 ADB Gender and Development (GAD) Policy, which adopts gender mainstreaming as a key strategy in promoting gender equity. ${ }^{5}$ Gender mainstreaming is defined in the ADB GAD Policy as requiring the explicit integration of gender considerations into all aspects of ADB operations. It begins with a gender analysis, which is a process of identifying the areas of inequality between women and men in different spheres (economic, political, sociocultural, institutional or organizational, etc.), as well as assessing "systematically the impact of programs and projects on men and women and on their economic and social relationships." Efforts in operationalizing these commitments and approaches have been demonstrated particularly by the South Asia Department as outlined in Box 1.

Box 1: Initiatives of the ADB South Asia Department in Mainstreaming Gender Equality and Social Inclusion in the Energy Sector: How This Tip Sheet Started

The preparation of this tip sheet evolved from the initiatives of the Asian Development Bank (ADB) South Asia Department (SARD) in mainstreaming gender equality and social inclusion (GESI) ${ }^{a}$ in its energy sector portfolio. These initiatives began in 2010 with the implementation of the regional grant, Improving Gender-Inclusive Access to Clean and Renewable Energy in Bhutan, Nepal, and Sri Lanka, as an entry point for mainstreaming GESI in three ADB-financed energy sector projects in three developing member countries (DMCs). The results of this grant-as well as of other related initiatives of SARD DMCs and ADB energy staff-were presented in the Subregional Conference on Going Beyond the Meter: Inclusive Energy Solutions in South Asia held in Jaipur, Rajasthan, India on 11-12 April 2016. This subregional

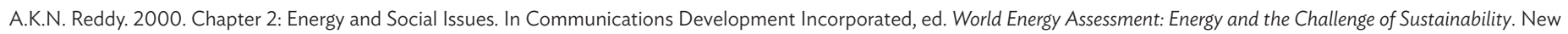
York: United Nations Development Programme. pp. 39-60.

Footnote 1, p. 44.

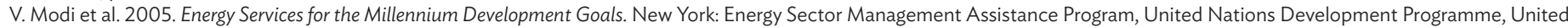
Nations Millennium Project, and World Bank. p. 9.

ADB. 2008. Strategy 2020: The Long-Term Strategic Framework of the Asian Development Bank 2008-2020. Manila.

ADB. 2010. Gender and Development in ADB Operations. Operations Manual. OM C2/BP. Manila.

Footnote 5, p. 1. 
conference generated greater interests among SARD DMCs and energy division staff, and led to the participation of key officials of SARD DMCs and ADB staff in the 5-day Deep Dive Lateral Learning Program on Inclusive Energy Solutions in the University of Melbourne School of Engineering, Australia on 29 August-2 September 2016

In this tip sheet, SARD translates into framework and tools the lessons learned from these initiatives. The purpose is to provide the staff, consultants, and executing and implementing agencies of ADB - not only in South Asia but also in other subregions-with a framework and set of guides for mainstreaming GESI in energy programs and projects. It serves to supplement ADB's Gender Toolkit: Energy Going Beyond the Meter, Tip Sheet No. 1: Understanding and Applying Gender Mainstreaming Categories, Tip Sheet No. 2: Preparing a Project Gender Action Plan, Tip Sheet No. 4: Project Reviews: Monitoring and Reporting on Gender Action Plans, and Tip Sheet No. 5: Gender-Inclusive Results in Project Completion Reports. ${ }^{a}$

a In the context of South Asia, gender analysis spans across gender equality and social inclusion (GESI) considerations, hence the use of GESI analysis, GESI indicators and targets and GESI-related results

b ADB. Gender Tip Sheets. https://www.adb.org/documents/series/gender-tipsheets?page=1)

Source: Author.
To apply the above GAD Policy, a proposed loan, grant, or technical assistance program or project, based on the results of a gender analysis as well as its target outcomes and outputs, is classified during project design phase into any of four gender categories: (i) gender equity theme (GEN), if deemed to primarily and directly respond to gender issues and concerns; (ii) effective gender mainstreaming (EGM), if focused on issues or problems that are not directly related to gender needs and concerns but can significantly contribute to gender equality and women's empowerment; (iii) some gender elements (SGE), if not fully relevant to gender concerns but has some aspects where gender considerations could be integrated; and (iv) no gender elements (NGE), if not at all relevant to gender concerns or if gender-related considerations could only be integrated in the project's social safeguards framework or plan. A GEN or EGM categorization signals the project designers to include genderrelated performance targets and indicators in the project's design and monitoring framework, prepare a gender action plan (GAP) and allocate adequate resources (human, funds, and materials) for the implementation of the GAP.

\section{Framework: Gender Equality in Energy Development}

In this tip sheet, a framework refers to the lens or perspective for defining the road map to achieving gender equality results in the energy sector. The framework presented here posits that the road map should consist of three gender action areas: target results, enablers, and yardstick. Table 1 presents a definition of each action area and its main elements.

\section{Table 1: Gender Equality and Social Inclusion Framework for the Energy Sector}

\begin{tabular}{|c|c|}
\hline Action Areas & Main Elements of Gender Mainstreaming in ADB Energy Sector Portfolio \\
\hline $\begin{array}{l}\text { Gender Equality } \\
\text { Results: desired } \\
\text { contributions } \\
\text { of an energy } \\
\text { program or } \\
\text { project to gender } \\
\text { equality results }\end{array}$ & $\begin{array}{l}\text { An energy program or project contributes to gender equality results if it is aimed at responding to the empowerment needs of } \\
\text { low-income households, especially and disadvantaged women, through the following: } \\
\text { - Increasing the accessibility of clean (i.e., non-coal) and/or renewable energy resources (solar, wind, and hydro) and modern } \\
\text { energy services for disadvantaged communities (especially in rural areas) } \\
\text { - Improving the affordability of energy resources and services } \\
\text { - Expanding women's employment opportunities and participation in the management of the energy sector, which is } \\
\text { dominated by men } \\
\text { - Providing women with opportunities for energy-based livelihoods (e.g., assembling and repairing compact fluorescent } \\
\text { light bulbs, pottery making using electric pottery wheels, tailoring using electric sewing machines, bag making using electric } \\
\text { machines, etc.) } \\
\text { - Optimizing the benefits and efficiency of energy for health, safety, education, and well-being }\end{array}$ \\
\hline
\end{tabular}


Gender equality enablers: factors that can facilitate the achievement of gender equality results

Partnership of energy service providers (from public and private or business sectors) and energy service users (represented by their own community-based organizations and supported by nongovernment organizations) is crucial in achieving the envisaged gender equality results. Capacity to engage in this partnership and to contribute to the achievement of gender equality results can be strengthened through the following:

\section{Service Providers (Supply Side)}

- Formulating enabling laws and policies that mandate the management and staff of government energy agencies and utility companies to mainstream gender in their energy programs and/or projects

- Bridging the gap in the proportion of women to men electrical engineers and energy project managers and staff by promoting the entry of more women in energy-related careers and jobs, such as through information, communication, education campaigns, and other government programs that encourage girls and young women to choose energy-related careers, provide scholarships, ensure job placements, and identify model women in energy-related careers

- Capacity development of management and staff in gender mainstreaming in energy program and/or project development and in their internal operations and work environment

- Training women electrical technicians in on-grid and off-grid operations and maintenance

- Developing and implementing programs, projects, and instruments for better access to, and safe and productive use of, energy (e.g., providing off-grid generation capacity in remote rural communities, alternative financial instruments or mechanisms to make energy affordable to disadvantaged households, modern cookstoves, etc.)

- Promoting unskilled employment for women in civil works and electromechanical works

- Designating a gender focal point in program and/or project management structure

- Allocating a budget for gender mainstreaming activities

\section{Service Users (Demand Side)}

- Raising awareness on the equal worth and rights of women and girls and men and boys in the households, communities, organizations, workplaces, and other spheres of life

- Ensuring equitable representation of women and men in energy user structures ${ }^{a}$ and their equal participation in decisionmaking

- Developing the capacities of women and disadvantaged groups in using energy resources safely and productively (including for livelihood and business development)

- Improving access to finance for energy access and energy-based livelihood as well as access to market linkages

- Developing the leadership capacity of women

- Forming and sustaining partnership with service providers (public and private) for knowledge exchange, resource mobilization, and sustained quality of services

\section{Gender Equality}

\section{Yardstick:}

measurement of

the effectiveness

and efficiency

of the gender

\section{equality}

\section{enablers, and}

the extent of the

achievement of

gender equality

results
To monitor the progress and evaluate the relevance, efficiency, and effectiveness of gender equality enablers, as well as the sustainability of gender equality results of an energy program and/or project, the following features should be integrated in the energy program and/or project monitoring and evaluation framework:

- Disaggregation of data (e.g., participants, electrical engineers, community technicians, project managers and staff, beneficiaries, etc.) by sex and disadvantaged groups

- Performance indicators related to the gender equality results and enablers

- Inclusion of an analysis of sex-disaggregated data and status of gender performance indicators in progress and completion reports

$\mathrm{ADB}=$ Asian Development Bank.

a An example of energy user structure is the electricity user groups in Nepal and its network, the National Association of Community Electricity Users Nepal.

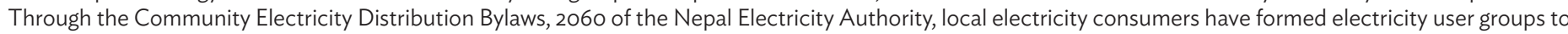
participate in the distribution management of grid-based electrification and facilitate the lighting of their communities.

Source: Author. 


\section{Defining the Gender Category of an Energy Program or Project}

In $A D B$, the designing of an energy program or project begins with the formulation of a program or project concept paper. At this stage, a preliminary gender category is assigned. In line with the ADB Guidelines for Gender Mainstreaming Categories of ADB Projects ${ }^{7}$ and Tip Sheet No. 1: Understanding and Applying Gender Mainstreaming Categories, 8 Table 2 presents key conditions and requirements for classifying an energy program or project under any of the four gender categories.

Even if a project is categorized as NGE, the responsible teams must still ensure that the program and/or project does not discriminate against women and other disadvantaged groups. The four gender categories could be arranged and located in a spectrum of gender mainstreaming actions as follows:

If a program or project is categorized as GEN, EGM, or SGE, please refer to the next sections for further guidance and to ADB Tip Sheet No. 1 for design criteria and; and if categorized as NGE, see section on Monitoring and Evaluation: Gender Equality Yardstick during Project Implementation and at Project Completion of this tip sheet.
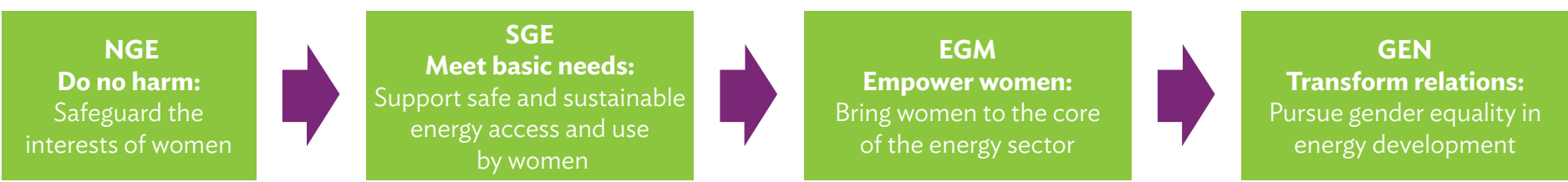

\section{Table 2: Points to Consider in Determining the Gender Classification of Proposed Energy Programs and Projects}

\begin{tabular}{|c|c|c|}
\hline Gender Category & Conditions for Classification & Requirements (What Must Be Done) \\
\hline $\begin{array}{l}\text { Gender equity } \\
\text { theme (GEN) }\end{array}$ & $\begin{array}{l}\text { The program or project is designed } \\
\text { to directly address key gender issues } \\
\text { in energy development and achieve } \\
\text { gender equality results. }\end{array}$ & $\begin{array}{l}\text { - Substantially discuss gender issues in the Rationale section of the program or } \\
\text { project documents - report and recommendation of the President (RRP), and } \\
\text { project administration manual (PAM). } \\
\text { - Incorporate gender targets and indicators in target outcome and outputs of the } \\
\text { design and monitoring framework (DMF). } \\
\text { - Develop a gender action plan consistent with the gender targets and indicators of } \\
\text { the project's DMF. } \\
\text { - Provide adequate human and financial resources for the implementation of the } \\
\text { Gender action plan. }\end{array}$ \\
\hline $\begin{array}{l}\text { Effective gender } \\
\text { mainstreaming } \\
(\text { EGM) }\end{array}$ & $\begin{array}{l}\text { The program or project is not designed } \\
\text { to directly address gender issues, but } \\
\text { can significantly contribute to gender } \\
\text { equality results. }\end{array}$ & $\begin{array}{l}\text { - Incorporate gender targets and indicators in } 50 \% \text { of the DMF outputs. } \\
\text { - Develop a gender action plan consistent with the gender targets and indicators of } \\
\text { the project's DMF, and attach this plan in the RRP and integrate in PAM Section } \\
\text { VIII (Gender and Social Dimensions). } \\
\text { - Provide adequate human and financial resources for the implementation of the } \\
\text { gender action plan. }\end{array}$ \\
\hline $\begin{array}{l}\text { Some gender } \\
\text { elements (SGE) }\end{array}$ & $\begin{array}{l}\text { The program or project is not expected } \\
\text { to significantly contribute to gender } \\
\text { equality results due to minimal or lack } \\
\text { of interface with end users, but some } \\
\text { gender equality enablers could be } \\
\text { integrated in the project design. }\end{array}$ & $\begin{array}{l}\text { - Include at least two gender features, which need to be specified in an appropriate } \\
\text { RRP (not necessarily in the DMF) section and in PAM Section VIII (Gender and } \\
\text { Social Dimensions). } \\
\text { - Gender features should be in addition to the gender elements of the social } \\
\text { safeguards framework or plan (e.g., consultations with women and men affected } \\
\text { by the project; ensuring just compensation for all affected people, especially } \\
\text { households headed by women) and core labor standards (equal work opportunities, } \\
\text { equal pay for equal work, awareness campaign on sexually transmitted infections). }\end{array}$ \\
\hline $\begin{array}{l}\text { No gender } \\
\text { elements (NGE) }\end{array}$ & $\begin{array}{l}\text { The program or project is not expected } \\
\text { to directly benefit and engage people in } \\
\text { project areas and end users, and hence } \\
\text { is not relevant to the gender equality } \\
\text { thrust. }\end{array}$ & $\begin{array}{l}\text { - Gender features are not required, but proponent should ensure that both women } \\
\text { and men in project areas are consulted during design phase and gender-responsive } \\
\text { social safeguards measures are in place if the project is Category A or B under the } \\
\text { ADB involuntary resettlement and indigenous people social safeguards policies. }\end{array}$ \\
\hline
\end{tabular}

Source: ADB. 2012. Guidelines for Gender Mainstreaming Categories of ADB Projects. Manila.

ADB. 2012. Guidelines for Gender Mainstreaming Categories of ADB Projects. Manila.

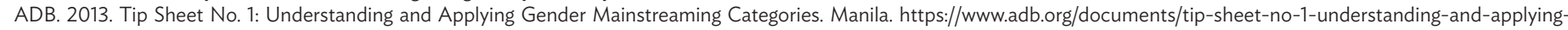
gender-mainstreaming-categories 


\section{Gender Assessment: Defining the Gender Equality Context and Targets of Proposed Energy Program and/or Project}

This section presents sets of questions (Table 3) that can be used as a guide for the collection of baseline data for the gender performance targets and indicators of the design and monitoring framework (DMF) as well as of the gender action plan of GEN- and EGM-categorized programs and/ or projects. Some questions may also be used to confirm the SGE categorization of a program or project and to identify its relevant gender features.

\section{Table 3: Gender Performance Indicators and Questions for Data Gathering and Assessment}

\begin{tabular}{|c|c|}
\hline Sample Gender Indicators for the DMF and GAP & ns for Baseline Data Gathering and Project Assessment \\
\hline \multicolumn{2}{|l|}{ Gender Equality Results } \\
\hline $\begin{array}{l}\text { Increased accessibility of clean (i.e., non-coal) and/or renewable } \\
\text { energy (solar, wind, and hydro) } \\
\text { - Increased number of disadvantaged households and households } \\
\text { headed by women with access to clean energy } \\
\text { - Decreased time spent or travel distance to access energy sources } \\
\text { by disadvantaged women and men } \\
\text { - Increased hours for studying } \\
\text { - Increased access to media (radio and TV) }\end{array}$ & $\begin{array}{l}\text { - What are the energy sources of disadvantaged households in the program } \\
\text { and/or project areas? What energy sources are used for the tasks and } \\
\text { needs of women and of men? } \\
\text { - How many disadvantaged households (including households headed by } \\
\text { women) have access to clean energy? } \\
\text { - What is the average number of study hours of students? } \\
\text { - What media do women and men use to access information? How many } \\
\text { have radios and TVs? }\end{array}$ \\
\hline $\begin{array}{l}\text { Improved affordability of energy } \\
\text { - Increased number of disadvantaged households and households } \\
\text { headed by women with access to energy } \\
\text { - Decreased cost of energy sources for households, livelihood or } \\
\text { enterprises, agricultural production } \\
\text { - Presence of alternative financial instruments to help disadvantaged } \\
\text { households afford energy sources and energy-based appliances }\end{array}$ & $\begin{array}{l}\text { - How much do households spend to access (installation cost) and use } \\
\text { (consumption cost) energy and/or electricity? } \\
\text { - How much energy cost is used for livelihood and production? } \\
\text { - What financial mechanisms are in place to help disadvantaged } \\
\text { households afford the cost of installation and consumption of energy? } \\
\text { - If there are no financial support mechanisms, where do disadvantaged } \\
\text { households get the funds to pay for energy installation and consumption? }\end{array}$ \\
\hline $\begin{array}{l}\text { Increased opportunities for energy-based livelihood } \\
\text { - Increased number of women-led enterprises benefiting from } \\
\text { available or productive use of energy } \\
\text { - Increased number of loans or other financial products disbursed } \\
\text { to energy-based enterprises owned by women or with majority } \\
\text { women workers } \\
\text { - Increased income of women }\end{array}$ & $\begin{array}{l}\text { - How many energy-based livelihoods have been put up as a result of the } \\
\text { program or project? What is their average working hours? } \\
\text { - How many women-led livelihood or enterprises benefit from productive } \\
\text { use of energy? } \\
\text { - What financial products are available for energy-based enterprises owned } \\
\text { by women? } \\
\text { - What are the effects of energy interventions on women's income and } \\
\text { household expenditures? }\end{array}$ \\
\hline $\begin{array}{l}\text { Optimized benefits and efficiency of energy for health, sa } \\
\text { education, and well-being } \\
\text { - Reduced workload of women in the households } \\
\text { - Increased use of modern cooking technology } \\
\text { - Number of improved public services (e.g., health services) } \\
\text { - benefiting from energy } \\
\text { - Decreased cases of illnesses due to indoor pollution } \\
\text { - Improved sense of safety among women }\end{array}$ & $\begin{array}{l}\text { - What are the effects of the lack and presence of electricity on the } \\
\text { - workload of women in the households? } \\
\text { - What energy sources do households use for cooking? } \\
\text { - Which public services improved due to energy? } \\
\text { indoor pollution brought about by traditional cooking method? (Provide } \\
\text { sex-disaggregated data.) } \\
\text { - What are the effects of the lack of streetlights on women's mobility? }\end{array}$ \\
\hline
\end{tabular}


Sample Gender Indicators for the DMF and GAP

\section{Employment in the energy sector}

- Increased proportion of women employed in government energy agencies and utility companies at different levels of the structure

- Increased number of women (in the communities) trained in and contracted for on-grid and off-grid operations and maintenance
Questions for Baseline Data Gathering and Project Assessment

- What is the proportion of women employees to men employees in the government energy agencies and utility companies implementing agencies at the managerial, technical, and administrative levels?

- What is the proportion of women in office- and field-based jobs?

- How many women in the communities are trained in and contracted for on-grid and off-grid operations and maintenance?

\section{Gender Equality Enablers}

\section{Enablers: Service Providers (Supply Side)}

- Presence of laws and policies that mandate all units (management and staff) to mainstream gender in energy program and/or project development

- Proportion of managers and staff trained in gender and development, and gender mainstreaming

- Proportion of women to men electrical engineers, women to men managers, and women to men staff in the implementing agency

- Presence of mechanisms (e.g., GAP, gender focal persons, gender budget, etc.) to facilitate gender mainstreaming

- Presence of training program for women electrical technicians

\section{Enablers: Service Users (Demand Side)}

- Recognition of the equal rights of women/girls and men/boys to energy resources and services

- Proportion of women in energy user structures (if any) and in community decision-making and governance structures

- Number of women (compared to men) trained in the safe and productive use of energy or electricity

- Number of women (compared to men) trained in energy-based enterprise development
- What policies and laws support gender mainstreaming in energy programs and/or projects? What laws and policies are needed to facilitate gender mainstreaming?

- How many managers and staff of the implementing agencies are trained in gender and development, and gender mainstreaming?

- Compared to men, how many are women electrical engineers, managers, and staff in the implementing agency?

- Does the implementing agency have a gender focal point who is tasked to ensure gender mainstreaming in the energy program and/or project?

- Does the agency allocate a gender budget?

- Does the agency have a training program for women electrical technicians? If yes, how many women have undergone the training?

- Who in the households makes decisions on accessing and using electricity? Women or men?

- Are there energy user structures in the program or project sites? If yes, what is the proportion of women in the structures? What is the proportion of women in the decision-making structures?

- Have awareness or training sessions on the safe and productive use of energy or electricity been conducted in the program or project sites? If yes, how many women and men were trained?

- Compared to men, how many women in program or project sites are trained in energy-based enterprise development?

$\mathrm{DMF}$ = design and monitoring framework, GAP = gender action plan.

Source: Author

Data collection could be through review of secondary data, focus group discussions, and key informant interviews. If financial and time resources are available, baseline surveys could also be done. Based on the results of the gender assessment, the initial gender category is validated, baseline data of gender targets and indicators in the DMF are set, and GAP is prepared. The GAP is attached to the report and recommendation of the President (RRP)-as a linked document-and project administration manual (PAM) and facility administration manual (FAM) of the energy program or project. 


\section{Planning and Implementation Guide}

Table 4 presents additional key points to consider when planning for possible gender-related entry points in projects for each energy subsector.

\section{Table 4: Entry Points for Mainstreaming Gender in Projects per Energy Subsector}

\begin{tabular}{|c|c|}
\hline Energy Subsectors & Gender-Related Entry Points \\
\hline $\begin{array}{l}\text { Power generation and } \\
\text { transmission }\end{array}$ & $\begin{array}{l}\text { - Provide investments in streetlights } \\
\text { - Improve quality of power supply for households and livelihood } \\
\text { - Train management and staff of energy utilities in mainstreaming gender and development in energy projects } \\
\text { - Promote unskilled employment for interested women in civil works and electromechanical works } \\
\text { - Develop gender-responsive resettlement plans and risk mitigation measures } \\
\text { - Train women and disadvantaged communities in power generation and transmission }\end{array}$ \\
\hline $\begin{array}{l}\text { Distribution (e.g., rural } \\
\text { electrification) }\end{array}$ & $\begin{array}{l}\text { - Increase the number of electrified disadvantaged households, including all households headed by women } \\
\text { - Provide institutional electrification for schools and hospitals } \\
\text { - Provide street lighting } \\
\text { - Strengthen women's participation and leadership in community-managed decentralized distribution systems } \\
\text { through capacity building and quota system } \\
\text { - Maximize opportunities for energy-based women's entrepreneurship and related skills training } \\
\text { - Maximize women's skilled and semi-skilled employment opportunities in the energy sector through technical } \\
\text { - training and quota system } \\
\text { - Conduct gender-sensitivity training of stakeholders for the implementation of the GAP }\end{array}$ \\
\hline Renewable energy & $\begin{array}{l}\text { - All of the above } \\
\text { - Ensure women's participation in skilled national and local labor force for renewable energy development } \\
\text { - Promote women as service providers in renewable energy systems and technologies } \\
\text { - Promote targeted investments in renewable energy technologies to maximize impacts on gender equality and } \\
\text { - } \text { - Addremen's empowerment }\end{array}$ \\
\hline Energy efficiency & $\begin{array}{l}\text { - Improve quantity (24-7) and quality of supply to benefit women and men in disadvantaged communities } \\
\text { - Develop energy efficiency programs that benefit women and disadvantaged household consumers, women-led } \\
\text { micro and small enterprises, farmers, and others }\end{array}$ \\
\hline
\end{tabular}

Source: Reihana Mohideen, PhD, Senior Consultant for Gender in Energy of ADB South Asia Department.

The GAP is prepared using the matrix in Table 5. Eight points must be kept in mind in preparing the GAP: (i) the output statements should be the same as those of the DMF; (ii) an activity is to be undertaken to achieve a target or set of targets, and should be phrased as an activity statement beginning with a verb; (iii) gender-related targets and indicators of the DMF must be included in the second column of the GAP with corresponding activities; (iv) more gender-related targets and indicators (apart from those in the DMF) could be added as long as they are related to the target outputs and outcomes of the program or project; ( $v$ ) the timelines of GAP activities must be consistent with the timelines of corresponding activities with milestones of the DMF; (vi) all abbreviations must be defined at the end of the GAP table; (vii) the GAP must have a maximum of two pages including the defined abbreviations, and presented preferably in landscape format for ease of reference and update; and (viii) the right header must have the project name, country code, and project number (see sample GAP in Table 5). Refer to Tip Sheet No. 2: Preparing a Project Gender Action Plan for other points to consider. 
Table 5: Sample Gender Action Plan

Preparing Outer Islands for Sustainable Energy Development Project (RRP MLD 46122)

Gender Action Plan

\begin{tabular}{|c|c|c|c|}
\hline Activities & Targets/Indicators & Responsibility & Time Frame \\
\hline \multicolumn{4}{|c|}{ Output 1: Renewable-energy-ready grid systems developed for outer islands and Greater Male' region } \\
\hline $\begin{array}{l}\text { Activity 1.1: Conduct social preparation activities } \\
\text { (before introduction of renewable energy project) in } \\
\text { each project-covered island }\end{array}$ & $\begin{array}{l}\text { Target/Indicator 1.1: Household surveys for } \\
\text { social and gender impact assessment conducted } \\
\text { in } 80 \text { islands (Target: Household survey report } \\
\text { including an assessment of the use of energy by } \\
\text { women and the possible drivers and barriers to } \\
\text { their participation in the promotion of renewable } \\
\text { energy) }\end{array}$ & $\begin{array}{l}\text { FENAKA, PMU, Social/ } \\
\text { gender development } \\
\text { specialist, STELCO }\end{array}$ & 2016-2017 \\
\hline \multicolumn{4}{|c|}{ Output 2: Enhanced capacity of the MEE, STELCO, and FENAKA to implement renewable energy grid interventions } \\
\hline $\begin{array}{l}\text { Activity 2.1: Develop a road map for outer island } \\
\text { transition to renewable energy }\end{array}$ & $\begin{array}{l}\text { Target/Indicator 2.1: Gender equality } \\
\text { interventions in the Strategic Action Plan of the } \\
\text { Government of Maldives and FENAKA's CSR } \\
\text { Program reflected in the road map }\end{array}$ & FENAKA, PMU & 2016-2018 \\
\hline $\begin{array}{l}\text { Activity 2.2: Train FENAKA and STELCO staff in } \\
\text { implementing the road map for renewable energy } \\
\text { systems, in scaling up proven solutions, and in } \\
\text { mainstreaming gender in renewable energy projects } \\
\text { and gender-inclusive community outreach }\end{array}$ & $\begin{array}{l}\text { Target/Indicator 2.2: } 60 \text { FENAKA and STELCO } \\
\text { staff trained in the implementation of the road } \\
\text { map, gender-inclusive community outreach, } \\
\text { and mainstreaming gender in renewable energy } \\
\text { projects (Target: at least } 25 \% \text { women participants; } \\
\text { at least one training session per project phase) }\end{array}$ & $\begin{array}{l}\text { FENAKA, PMU, Social/ } \\
\text { gender specialist }\end{array}$ & 2016-2019 \\
\hline
\end{tabular}

$\mathrm{CSR}=$ corporate social responsibility, MEE = Ministry of Environment and Energy, PMU = project management unit, STELCO = State Electricity Company.

Source: ADB South Asia Department.

\section{Monitoring and Evaluation: Gender Equality Yardstick during Project Implementation and at Project Completion}

\section{Gender Action Plan Implementation Monitoring Report}

Include in the appendix of the PAM or FAM a template for the quarterly GAP implementation monitoring report (Table 6). This report should be attached to the program or project's quarterly progress report. In preparing this report, ensure that (i) the data or information correspond to or are consistent with the activity or target on the same row; (ii) the data or information are understandable to an external reader (it would help to provide both quantitative data-e.g., number of women and men participants and beneficiaries-and qualitative data-e.g., overview of types of contributions and benefits of women; (iii) activities and achievements on the second column are updated (activities were done and targets were achieved during the quarter); and (iv) the reasons for the nonperformance of activities and/or nonachievement of targets are well explained in the last column. See Tip Sheet No. 4: Project Reviews: Monitoring and Reporting on Gender Action Plans for other key points. 
Table 6: Sample Gender Action Plan Implementation Monitoring Report Matrix

GAP Implementation Monitoring Report of Nepal: Tanahu Hydropower Project

Evaluation period (quarter):

\begin{tabular}{|c|c|c|c|}
\hline \multirow[b]{2}{*}{ Gap Activities and Targets/Indicators } & \multicolumn{2}{|c|}{ Progress to Date } & \multirow[b]{2}{*}{$\begin{array}{c}\text { Issues and } \\
\text { Challenges (Reasons } \\
\text { for delay, } \\
\text { non-implementation } \\
\text { of activities, } \\
\text { or non-achievement } \\
\text { of targets) }\end{array}$} \\
\hline & $\begin{array}{l}\text { Progress for the } \\
\text { Current Quarter } \\
\text { (Activities and } \\
\text { Achievements- } \\
\text { quantitative and } \\
\text { qualitative for the } \\
\text { current quarter) }\end{array}$ & $\begin{array}{l}\text { Cumulative Progress } \\
\text { (Activities and } \\
\text { Achievements- } \\
\text { quantitative and } \\
\text { qualitative-for the } \\
\text { pass and current }\end{array}$ & \\
\hline \multicolumn{4}{|l|}{ Output 1: Hydropower paint and transmission system made operational } \\
\hline \multicolumn{4}{|l|}{ Activity 1.1 Conduct participatory and meaningful consultations } \\
\hline \multicolumn{4}{|l|}{$\begin{array}{l}\text { Target } 1.1 \text { Three-broad based and socially inclusive consultations on } \\
\text { gender equality and CDS goals, objectives, and status conducted: in each } \\
\text { VDC (Target: at least 1,000 participants, } 60 \% \text { women and socially excluded } \\
\text { persons (SEP) }\end{array}$} \\
\hline \multicolumn{4}{|l|}{$\begin{array}{l}\text { Target 1.2 Awareness raising sessions and events conducted on gender } \\
\text { equality, women's empowerment, and legal entitlements and rights of } \\
\text { women and girls (Target: 1,000 participants, 50\% women) }\end{array}$} \\
\hline \multicolumn{4}{|l|}{ Output 2: Rural electrification increased } \\
\hline \multicolumn{4}{|l|}{ Activity 2.1 Increase access to electricity } \\
\hline $\begin{array}{l}\text { Target 2.1 Additional 17,636 households electrified (Target: 100,000 } \\
\text { beneficiaries, 50\% women, 1,700 FHH) }\end{array}$ & & & \\
\hline
\end{tabular}

Prepared by:

Date:

$\mathrm{CDS}=$ community development strategy, $\mathrm{FHH}=$ female-headed household, $\mathrm{GAP}=$ gender action plan, VDC = village development committee

Source: ADB South Asia Department.

\section{Ensuring Gender Sensitivity of Project Completion Reports}

ADB projects and the gender-related aspects therein are assessed at completion based on four criteria: relevance, effectiveness, efficiency, and sustainability. Sex-disaggregated results of the assessments-demonstrating reductions in gender disparities against baseline indicators-are presented in a project completion report (PCR). Tip Sheet No. 5: GenderInclusive Results in Project Completion Reports describes the gender aspects of the four criteria as follows:

- relevance of gender issues to project objectives and whether gender was adequately mainstreamed in project design and implementation;

- effectiveness of GAP (if any) and gender-related outcomes, outputs, targets, and indicators in the DMF;
- efficiency of project's resource allocation (both human and financial) for GAP implementation and monitoring; and

- likely sustainability of project outcomes on gender equality and women's empowerment based on both quantitative data and qualitative impact assessments.

The PCR evaluates the relevance, effectiveness, efficiency, and likely sustainability of the outcomes of the GAP at the project level. It should specifically state what worked, what did not work, their underlying reasons, lessons learned, and recommendations on how to improve gender mainstreaming in the design of new projects to enhance ADB's contributions to gender equality results. ${ }^{9}$ As feasible, this may also include a general assessment of immediate outcomes for gender equality and women's empowerment.

In addition to the above, the evaluation also includes an assessment of the extent of completion of each activity and

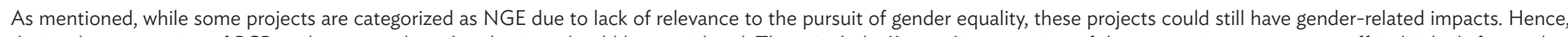

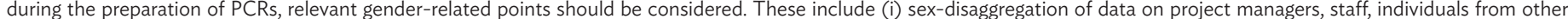

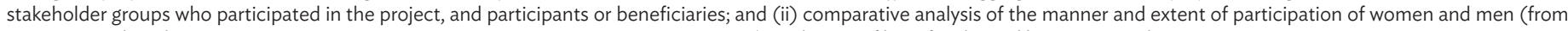
executing and implementing agencies, nongovernment organizations, communities, etc.), and types of benefits derived by women and men.
} 
target. To be deemed successful, a GAP completion should have at least $70 \%$ of the activities fully accomplished and $75 \%$ of the quantitative targets achieved. To present this assessment, the template in Table 7 is used and attached in an appendix of the PCR. The tips in effectively using this template are the same as the first two tips for GAP implementation monitoring report.

\section{Table 7: Sample Template of Gender Action Plan at Project Completion}

\begin{tabular}{|l|l|l|}
\hline $\begin{array}{l}\text { GAP Activities and Targets } \\
\text { (List here all activities and targets in the GAP, and number } \\
\text { the activities continuously for easier counting. The actual } \\
\text { number and statement of the outputs, activities, and targets } \\
\text { should be the same as those in the GAP of assessed program } \\
\text { or project) }\end{array}$ & $\begin{array}{l}\text { Accomplishments } \\
\text { (Briefly state here the quantitative and qualitative } \\
\text { achievements of each activity and target) }\end{array}$ & $\begin{array}{l}\text { Overall Assessment } \\
\text { (State here if the activity or } \\
\text { target was achieved or not } \\
\text { achieved) }\end{array}$ \\
\hline Output (as stated in the GAP) & & \\
\hline Activity 1 (as stated in the GAP) & & \\
\hline Target 1.1 (as stated in the GAP) & & \\
\hline Target 1.2 & & \\
\hline Activity 2 & & \\
\hline Target 2.1 & & \\
\hline Target 2.2 & & \\
\hline Output 2 & & \\
\hline Activity 3 & & \\
\hline Target 3.1 & & \\
\hline Output 3 & & \\
\hline Activity 4 & & \\
\hline Target 4.1 & & \\
\hline Total number and overall percentage of completed activities & & \\
\hline Total number and overall percentage of achieved quantitative targets & \\
\hline
\end{tabular}

\section{South Asia Department Practices in Mainstreaming GESI in Its Portfolio}

Good practices and studies relevant to the program or project may be considered as reference in the preparation of a GAP. Box 2 shows some of the good practices of ADB South Asia Department (SARD), and Box 3 presents alternative financing schemes and models to facilitate energy access of disadvantaged households. Box 4 lists studies recently undertaken by SARD and some areas for further research to identify more innovative approaches in mainstreaming gender in energy projects.

\section{Box 2: Examples of Gender Mainstreaming Activities of ADB-Supported Projects in South Asia}

\section{Training Women on Energy-Based Livelihood}

The technical assistance (TA) 7831 Madhya Pradesh Enhancing Energy-Based Livelihoods for Women Micro-Entrepreneurs in India trained (i) 20,729 women to gain access to energy-based income-generating business opportunities; (ii) 517 women in self-help groups (SHGs) on business development services; and (iii) 506 SHG women members on gender and energy. This TA project was attached to the Madhya Pradesh Energy Efficiency Improvement Investment Program, which aimed to provide 24-hour electricity supply to 28 districts covered by the program toward, among others, enabling women to reduce their time spent for household tasks by $20 \%$, and children to increase their study time by $25 \%$. 


\section{Training Women to Become Electrical Engineers}

The difficulty to reach remote villages drove the Department of Renewable Energy (DRE) of the Government of Bhutan to develop local capacities in electricity operation, maintenance, and sustainability. The DRE partnered with ADB to implement a project funded by the Japan Fund for Poverty Reduction (JFPR) 9158 for the training of 153 village electrical entrepreneurs and electrical technicians, 31 or $20 \%$ of whom were women. The DRE also trained 50 women in the operation and maintenance of off-grid solar home systems. This serves as proof that women can also perform this traditionally male-associated job.

\section{Setting Up an e-Cluster in a Social Center}

In Bangladesh, the ADB TA project, Enabling Poor Women's Benefits from Enhanced Access to Energy in Hatiya Island, promoted the nexus of gender, energy, and livelihoods. The gender aspect focused on women of disadvantaged households, while the energy aspect focused on innovative technologies tailor-made to provide multirange energy-based services, including livelihood opportunities. The nexus or merging of gender, energy, and livelihoods is reflected in an e-cluster that is set up in a social center for social activities. An e-cluster is a container-based autarkic solar photovoltaic (PV) battery, with integrated indoor and outdoor LED lighting, direct current/alternating current (DC/AC) ventilation, PV water pumping and filtration, cold storage (freezers) for preserving fish catch, and internet facility. When located in a social center, an e-cluster can provide electricitybased services to women cooperatives - they can put up restaurants and handicraft shops, and connect to the internet.

\section{Engaging Civil Society Organizations in Mobilizing Community (including Women's) Participation}

In JFPR 9158: Improving Gender-Inclusive Access to Clean and Renewable Energy in Bhutan, Nepal, and Sri Lanka, the nongovernment organizations (NGOs) that implemented the project-Practical Action in Sri Lanka, Royal Society for Protection of Nature in Bhutan, and Centre for Rural Technology in Nepal (CRTN) - tapped the presence of government structures and fellow NGOs in reaching remote villages. They conducted community awareness sessions on safe and efficient use of electricity and trained women in the productive use of electricity and electricity-based microenterprises, including the repair of electrical appliances. Practical Action conducted studies to understand the motivation of villagers in using electricity. CRTN assigned field facilitators to support the project-assisted electricity user cooperatives in selecting and motivating women entrepreneurs to engage in energy-based income-generating activities.

Source: ADB. 2016. Subregional Conference on Going Beyond the Meter: Inclusive Energy Solutions in South Asia. Jaipur, Rajasthan, India. 11-12 April.

\section{Box 3: Alternative Financing Schemes and Business Models for Energy Access of Disadvantaged Households}

In South Asia, public and private energy service providers have devised alternative financing schemes and business models to enable lowincome households to access power supply. ADB supported the following two schemes:

- Public-private partnership business model for promoting solar home systems by the Infrastructure Development Company Limited, a state-owned infrastructure financing company of the Government of Bangladesh. Using this business model, the Infrastructure Development Company Limited (IDCOL) engages participating organizations (nongovernment organizations and microfinance institutes) in (i) selling and installing solar home system (SHS) products (e.g., solar panels, LED bulbs, etc.) to customer households by cash or credit; (ii) training the customers on how to use the SHS correctly; (iii) providing after-sales services; and (iv) collecting monthly payments. IDCOL provides funding and capacity building support to the participating organizations. A standards committee-composed of representatives from prominent engineering universities, local government institutions, Ministry of Power, and others—checks the quality of products of eligible suppliers. Dedicated technical inspectors visit the households to check the installation and services provided. An operations committee, headed by the chief executive officer of IDCOL, meets monthly to review the installation progress and efficiency of payment collection by the participating organizations and to develop solutions to operational and strategic issues. IDCOL maintains a call center where households lodge their complaints directly and IDCOL responds to complaints filed. Among the highlighted success factors were the (i) financial contribution of the households, which motivates the households to maintain the system properly because of guaranteed ownership after full loan payment; (ii) cost-efficient standardized technical design; (iii) quality control, after-sales service, and strong monitoring; (iv) development of local support industries largely contributing to the low system cost; (v) Bangladesh's microfinance experience; and (vi) support from the government and multiple development partners, including ADB, in ensuring a steady funding support.

- Establishment of a rural electrification fund by the Government of Sri Lanka to provide credit facilities to low-income households for electricity connection. The Ceylon Electricity Board manages the fund and offers a household a maximum loan of SLRs4,000 ( $\$ 285)$ to be paid in 6 years with an interest rate of $7 \%$. To manage the fund easier, the government uses a web-based monitoring and evaluation system - a household goes to the nearest consumer service center to apply for electricity connection and the service center submits the application to the area engineering department, which approves the application using a computer program. The approved application goes to the project implementation unit for the release of funds and electricity connection. Once service connection is provided, the project management unit informs the concerned division of Ceylon Electricity Board to start loan recovery. Through this fund, electricity has been connected to $98.5 \%$ of the households. 


\section{Box 4: ADB South Asia Department Studies and Ways Forward}

Recent studies on gender and energy undertaken by SARD are the following:

- ADB. 2018. Gender Equality and Social Inclusion Assessment of the Energy Sector: Enhancing Social Sustainability of Energy Development in Nepal. Manila.

- Tariff Appraisal Study: Balancing Sustainability and Efficiency with Inclusive Access

- Energy Technology Innovation in South Asia: Implications for Gender Equality and Social Inclusion

- ADB. Setting up of Baseline for "Madhya Pradesh Energy Efficiency Improvement Investment Program”. Unpublished.

- ADB. Impact Assessment of TA 7831 IND Enhancing Energy-Based Livelihoods for Women Micro-Entrepreneurs. Unpublished.

Operationally relevant areas for further research in South Asia and other regions are the following:

(i) Energy sector reforms

- How do ongoing energy sector regulations and subsidies on fuels like kerosene and electricity affect women and men? Do women and men face differential constraints on accessing electricity in the reforms scenario?

- What are the roles of project executing and implementing government and private agencies in creating an enabling environment to optimize gender benefits of energy (e.g., end user education; off-peak tariffs for women-led micro, small, and medium-sized enterprises; role of corporate social responsibility)

- What are the gender trends in employment in the energy sector?

(ii) Electrification

- In what ways can electrification provide opportunities for empowerment of women and girls in grid and off-grid projects? Do gendered approaches make wider access to electricity? What are the impacts of different forms of electrification on women, girls, men, and boys?

(iii) Energy access-related impacts

- What are the impacts of improved energy accessibility on women's time burden and gender roles in the households? Have traditional gender roles changed? Or do they remain intact with some changes?

- What are the impacts of energy services, or lack thereof, on health-care facilities, especially women and children in rural areas?

(iv) Productive uses

- What are the gendered impacts of energy access on productive uses? Does improved energy access increase the productivity of informal enterprise run by women? How? Can involving women in energy value chains (i.e., converting primary energy forms into consumable forms of energy) improve their welfare, economic empowerment, and agency? What complementary services are important to facilitate entrepreneurial activities by women? What strategies will maximize benefits for women?

\section{(v) Technology systems}

- What are some of the factors that determine and promote women's uptake of new technologies, including gender-friendly technologies (improved cookstoves, electrified agro-processing, domestic biogas)?

Source: Reihana Mohideen, PhD, Senior Consultant for Gender in Energy of ADB South Asia Department. Second Lateral Learning Program on Smart Grid Technologies and Implications for Inclusive Development, 2-6 October 2017. University of Melbourne, Australia.

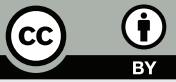

